\title{
A Possibility of utilization of Mallow (Malva sylvestris) and Hummayd (Rumex vesicarius) leaves for improving serum lipid profiles in hypercholesterolemic rats
}

\author{
Abd El-Moneim Samy Abd El-Moneim Hashish \\ Food Technol. Res. Inst., Agric. Res. Center, Giza, Egypt
}

\begin{abstract}
Mallow and hummayd leaves are Egyptian countryside common leafy vegetables. The aqueous extract of these leaves were used for estimating their total phenols and flavonoids contents and measuring the antioxidant activity. As well, mallow and hummayd leaves were cooked and mixed in ratios of 1:3, 1:2, 1:1, 2:1 or 3:1, respectively, and mixed with some natural additives for producing natural soup. The sensory evaluation of these products was carried out. Then, the biological assessment was done on rats fed a hypercholesterolemic diet to measure the effect of orally feeding mallow and hummayd leaves soup on the serum total fat and cholesterol levels. Also, body weight gain, food intake and food efficiency rate were measured.
\end{abstract}

Results showed that the total phenols and flavonoids content in the aqueous extract of the mallow leaves were $31.68 \mathrm{mg}$ gallic acid equivalent (GAE) $/ \mathrm{g}$ and $17.51 \mathrm{mg}$ quercetin acid equivalent $(\mathrm{QE}) / \mathrm{g}$, respectively. While the total phenols and flavonoids contents were $23.4 \mathrm{mg} \mathrm{GAE} / \mathrm{g}$ and $12.30 \mathrm{mg} \mathrm{QE} / \mathrm{g}$, respectively, in the aqueous extracts of hummayd leaves which is directly proportional to the antioxidant activity at rates $45.24 \%$ of mallow leaves and $28.13 \%$ of hummayd leaves. Generally, the sensory evaluation of these products showed high degrees for sensory acceptance. The 3 mallow: 1 hummayd leaves soup had the highest score. The results of the biochemical assessment showed that there was a significant decrease in the incidence of all levels of total cholesterol, triglycerides, low-density lipoprotein and very low density, while it was noted a significant increase in the level of high-density lipoprotein with increasing doses intake of blend soup.

In general, the current study illustrated the importance of mallow and hummayd leaves consumption and their values in reducing the weight and improving lipid profile. The study recommends, also, the inclusion in nutrition education programs to illustrate the importance of green leafy vegetables especially mallow and hummayd for being cheap and easy obtain.

\section{Introduction}

Leafy vegetables are known for their high minerals content. In particular, they are of interest for their therapeutic value, as being rich source of antioxidant, vitamins and pigments (Velvan et al., 2007 and Buyukokurglu et al., 2001). In food application, impetus of exploring natural antioxidant has given more interest to eliminate the synthetic product/drug. Oxidative damage is a critical etiological factor implicated in several chronic diseases such as diabetes mellitus, cancer, atherosclerosis, arthritis and neurodegenerative disease and also in the ageing process (Schuler, 1990).

Malva sylvestris belongs to the Malvaceae family. It is commonly known as common mellow in Europe (Mustafa and Ali 2011), khubaza in Egypt, tole in Iran, malva in Portugal, marva in Italy, and ebegümeci in Turkey (Tabaraki et al., 2012). Although it is found all around the world as a weed, its native regions are South Europe, North Africa, and 


\section{Abd El-Moneim Samy Abd El-Moneim Hashish}

Southwest Asia. The plant preferably grows in damp places like near oceans, marshes, ditches, river banks, and meadows (Razavi et al., 2011). It has shown potential therapeutic effects against various diseases (Jan et al., 2009; Pirbalouti et al., 2009 and Marouane et al., 2011).

Rumex vesicarius, locally called sorrel, hummayd and hammad (sour-wort), is a wild leafy plant that belongs to the family of Polygonaceae (Mandaville, 1990). Hummayd is a shrub that grows in the central and northern regions of Egypt and Saudi Arabia (Tukan et al., 1998) and common in other parts of the world, e.g. in India (Rao et al., 2011). The raw leave may be used as a salad ingredient added during the preparation of (dried milk shared) to increase the acidity (Tukan et al., 1998). The whole plant is medicinally important and cures several diseases. The plant is stimulant, tonic and acts as an aphrodisiac agent (El-Bakry et al., 2011). The plants of rumex, a large genus containing about 250 species, are known for different pharmacological activities including antimicrobial, anti-inflammatory, anti-analgesic and antioxidant (Tavares et al., 2010 and Gautam et al., 2010). In folkloric medicine, the plants are used for the treatment of tumors, cancers and diseases related to liver and urinary/kidney functions (Kathi and Kemper 1999).

Free radicals are highly reactive compounds, they are chemical species associated with an odd or unpaired electron and can be formed when oxygen interacts with certain molecules. They are neutral, short lived, unstable and highly reactive to pair with the odd electron and finally achieve stable configuration. Once formed these highly reactive radicals can start a chain reaction they are capable of attacking the healthy cells of the body, causing them to lose their structure and function. Cells may poorly function or die if this occurs (Ames et al., 1993).

Although in dietary practice, healthy plant-based diets do not necessarily have to be low in fat. Instead, these diets should include unsaturated fats as the predominant form of dietary fat (e.g., fats from natural liquid vegetable oils and nuts), an abundance of fruit and green vegetables, and adequate $\mathrm{n}-3$ fatty acids. Such diets, which also have many other health benefits, deserve more emphasis in dietary recommendations to prevent chronic diseases (Suido et al., 2002) Hyperlipidemia as a major risk factor of atherosclerosis is treated with different drugs. Concerning length of therapy and vast majority of side effects, herbal medication may be suitable for these drugs (Kojuri et al., 2007).

The current study aims to assess the mallow and hummayd leaves and their contents of total phenols and antioxidants activity. As well, production of mallow and hummayd leaves soup at different mixing levels, sensory evaluation and study the impact of the best treatment soup- obtained from sensory evaluation - on lipid profile in rats fed on hypercholesterolemic diet.

\section{Materials and Method}

1- Hummayd (Rumex vesicarius) and Mallow (Malva sylvestris) leaves were purchased from local market in Cairo. The plant was identified by Botany Department, Faculty of Agriculture, Menoufeya University and well preserved.

2- Cholesterol (white crystalline powder), bile salt, casein, vitamins, minerals and cellulose were obtained from ElGomhoriya Pharm. and Chem. Ind. Comp., Cairo, Egypt. Starch and corn oil were obtained from a local market.

\section{Methods:-}

Preparation of mallow and hummayd extracts:

Fresh mallow and hummayd leaves were dried and then powder-grinded. $25 \mathrm{~g}$ of each of the obtained dry powder was boiled separately in $100 \mathrm{ml}$ of water for $10 \mathrm{~min}$. and then filtered 


\section{Egypt. J. of Nutrition and Health Vol. 10 No. 1 (2015)}

\section{Chemical analysis:}

1- Total phenols and flavonoids contents in each plant materials were determined by folin-ciocalteu reagent by Arnous et al., (2001) and Joyeux et al., (1995), respectively.

2- Antioxidant activity of mallow and hummayd leaves were determined by the 1,1-diphenyl-2-picryl-hydrazyl (DPPH) method according to method of Brand-Williams et al., (1995).

3- Serum total cholesterol (TC), triglycerides (TG) and high density lipoprotein cholesterol (HDL-C) were measured using an enzymatic colorimetric test (Boehringer Mannheim Kits) according to Allain et al., (1974), Fossati and Prencipe (1982) and Lopes-Virella et al., (1977) methods, respectively. Very low density lipoprotein cholesterol (VLDL-c) and Low density lipoprotein cholesterol (LDL-cholesterol) were calculated using Friedewalde equations (Friedewalde et al., 1972) as follows:

$\operatorname{VLDL}(\mathrm{mg} / \mathrm{dl})=$ Triglycerides $/ 5$

$\operatorname{LDL}(\mathrm{mg} / \mathrm{dl})=($ Total cholesterol $-\mathrm{HDL})-\mathrm{VLDL}$

HDL-C/TC and LDL-C/HDL-C ratios were calculated.

\section{Preparation of mallow and hummayd leaves soup:}

Tomatoes, onions, garlic were chopped and cooked with clear chicken soup in the cooking pot about 15 min. and covered. Then, the chopped mallow and hummayd leaves, salt, rice and cumin were added. All components were cover again and cooked about $15 \mathrm{~min}$. The Ingredients of the prepared mallow and hummayd leaves soup were illustrated in table (1). An immersion blender was used. In the biological experiment, the puree was filtered to obtain clear vegetables soup.

Table (1):

The Ingredients of the prepared mallow and hummayd leaves soup.

\begin{tabular}{|c|c|c|c|c|c|c|}
\hline \multirow[t]{2}{*}{ Ingredients } & \multicolumn{6}{|c|}{ The tested ratios of mallow : hummayd } \\
\hline & $0: 0$ & $3: 1$ & $2: 1$ & $1: 1$ & $1: 2$ & $1: 3$ \\
\hline Mallow $(\mathrm{g})$ & - & 112.5 & 100 & 75 & 50 & 37.5 \\
\hline Hummayd (g) & - & 37.5 & 50 & 75 & 100 & 112.5 \\
\hline $\begin{array}{l}\text { Clear chicken } \\
\text { soup (ml) }\end{array}$ & 400 & 250 & 250 & 250 & 250 & 250 \\
\hline Tomato $(\mathrm{g})$ & 80 & 80 & 80 & 80 & 80 & 80 \\
\hline Onion (g) & 50 & 50 & 50 & 50 & 50 & 50 \\
\hline Butter (g) & 5 & 5 & 5 & 5 & 5 & 5 \\
\hline Garlic (g) & 5 & 5 & 5 & 5 & 5 & 5 \\
\hline Rice (g) & 10 & 10 & 10 & 10 & 10 & 10 \\
\hline Salt (g) & 2 & 2 & 2 & 2 & 2 & 2 \\
\hline Cumin (g) & 3 & 3 & 3 & 3 & 3 & 3 \\
\hline
\end{tabular}

\section{Organoleptic evaluation:}

The organoleptic characteristics of the stuffed vegetables leaves were done according to Larmond (1970). Ten panelists were asked to evaluate the appearance, viscosity, odour, taste and colour attributes of the prepared soup using score of 10 for each character. The average score for each character was calculated 
Experimental design:

Thirty male albino rats (weighing $125 \pm 10 \mathrm{~g}$ ) were housed in well-aerated wire cages. All animals were kept under a normal healthy condition and fed on basal diet for one week for adaptation. The basal diet consisted of casein $(10 \%)$, cellulose $(5 \%)$, corn oil $(10 \%)$, salt mixture $(4 \%)$, vitamin mixture $(1 \%)$ and the remained amount was starch according to Lane-Peter and Pearson (1971). After the adaptation period (7 days), they were divided into five groups, (6 rats in each group). The experimental animals were divided according the following scheme:

-The first group (negative control C-) was fed on basal diet only.

- The second group (positive control $\mathrm{C}+$ ) was fed on hypercholesterolemic diet (basal diet mixed with 1\% cholesterol, $0.25 \%$ bile salt and $15 \%$ beef tallow) in order to be hypercholesterolemia (Abdel- Raheim et al., 1995).

-The third group (T1) was fed on hypercholesterolemic diet and orally given $2 \mathrm{ml}$ of the prepared soup without hummayd and mallow leaves (1 $\mathrm{ml}$ at morning and $1 \mathrm{ml}$ at night).

- The fourth group (T2) was fed on hypercholesterolemic diet and orally given $2 \mathrm{ml}$ of the prepared (hummayd + mallow at rate $1: 3$ respectively) leaves soup ( $1 \mathrm{ml}$ at morning and $1 \mathrm{ml}$ at night).

- The fifth group (T3) was fed on hypercholesterolmic diet orally given $4 \mathrm{ml}$ of the prepared (hummayd + mallow at rate $1: 3$ respectively) leaves soup ( $2 \mathrm{ml}$ at morning and $2 \mathrm{ml}$ at night).

During the experimental period (4 weeks) each rat was weighed every week and food consumption was recorded. The body weight gain (BWG) and food efficiency ratio (FER) were determined according to Champman et al., (1959) by using the following formulas:

BWG $=[$ final weight $(\mathrm{g})-$ initial weight $(\mathrm{g})]$

FER $=[$ Body weight gain $(\mathrm{g}) /$ food intake $(\mathrm{g})] \times 100$

At the end of the experimental period, the tested rats were fasted over night before sacrificing and the blood was collected then centrifuged. The serum was separated and stored until analysis.

\section{Statistical analysis:}

Statistical analysis were performed by using computer program Statistical Package for Social Science (SPSS, 1998) and compared with each other using the suitable tests.

\section{Results and Discussion}

Total phenols and flavonoids contents:

Data presented in Table (2) observed that both plants extracts have high total phenolic and flavonoid contents. Mallow leaves aqueous extract have the higher phenolic value (31.68 mg GAE /g) and flavonoid (17.51 mg QE /g) contents, compared to hummayd (23.40 mg GAE /g and $12.30 \mathrm{mg} \mathrm{QE} / \mathrm{g}$, respectively). Several plants have been studied as sources of potentially safe natural antioxidants for the food industry and various compounds have been isolated with many of them being polyphenols. Previous results run parallel with El-Hawary et al., (2011) and Londonkar and Tukappa (2013) reported that extract of Rumex vesicarius had high amount of phenolic compounds. Recent studies have shown, also, that many flavonoids and related polyphenol significantly contribute to the total antioxidant activity in fruits and vegetables (Gil et al., 2000 and Marja et al., 1999).

\section{DPPH Free Radical Scavenging Assay:}

DPPH is a free radical stable at room temperature and produces a purple color solution in water. It is reduced in the presence of antioxidant molecule, giving a rose to yellowish aqueous solution. One of the mechanisms involved in antioxidant activity assay is the ability of a molecule to donate a hydrogen atom to a radical and the propensity of the 


\section{Egypt. J. of Nutrition and Health Vol. 10 No. 1 (2015)}

hydrogen donation is the critical factor involved in free radical scavenging (Jelili et al., 2011). Also, Table (2) showed the free radical scavenging activity of mallow and hummayd leaves extracts were assessed by the DPPH test. Both samples showed good free radical scavenging activities. The extract of mallow leaves showed $45.24 \%$ free radical inhibition followed by hummayd which expressed $28.13 \%$ inhibition.

\section{Sensory evaluation:}

Table (3) shows the sensory evaluation for different rates for mallow and hummayd leaves soup. Generally, all samples were acceptable by the sensory evaluation panel. The 3 mallow: 1 hummayd leaves soup had the highest score ( $97.87 \pm 0.57)$ followed by 2 mallow: 1 hummayd leaves soup $(96.15 \pm 0.78)$, while 1 mallow: 3 hummayd had the lowest score (92.65 \pm 0.35$)$. This may attributed to the acidic taste of hummayd leaves Tukan et al., (1998). This led the author to use the mixture of 3mallow: 1 hummayd in the experimental design.

\section{Nutrition parameters:}

Table (4) shows the mean values \pm SD of body weight gain (BWG), food intake (FI) and food efficiency ratio (FER) (\%) of rats as affected by different levels of mallow and hummayd contents of leaves soup. Results show that the highest mean value of body weight gain (BWG) $(36.95 \pm 1.31 \mathrm{~g})$ was found in group positive control $(\mathrm{C}+)$, while the groups that received the tested soups had BWG average more close to that of the normal group $(34.48 \pm 2.05,32.60 \pm 1.26$ and $29.94 \pm 2.15 \mathrm{~g}$ for groups T1, T2 and T3, respectively). Food intake showed an amount of $350.50 \pm 1.23 \mathrm{~g}$ for the negative group while the control positive, T1, T2 and T3 groups recorded lower values were $(294.75 \pm 2.70,298.70 \pm 3.10$, $309.50 \pm 2.35$ and $322.25 \pm 2.98 \mathrm{~g}$ ), respectively.

Although positive control group demonstrated the highest values of weight BWG and FER, the other hypercholesterolemic groups that received the tested soups with different levels of mallow and hummayd were significantly lower values compared with those of both negative and positive groups. Also, results demonstrated that with increasing the food intake of mallow: hummayd soup, BWG and FER values were decreased. The effect of both mallow and hummayd addition was proportional to their level, which might be ascribed to the higher fiber content of these diets. These diets are in the same line with those of Matos et al., (2005). The efficiency of these treatments in reducing body weight gain and food efficiency ratio could be a potential for reducing body weight and thus treating obesity.

\section{Serum lipid in hypercholesterolemic rats:}

Data presented in Table (5) demonstrated that rats fed with high cholesterol diet for seven days exhibited a significant increase in TC, TG, and LDL-c and a significant decrease in HDL-c as compared to normal animals group. The oral administration of mallow and hummayd leaves soup at levels 1 and $2 \mathrm{ml}$ twice daily caused a significant decrease in serum LDL-C, TG and TC levels with a significant increase in HLD-c $(p<0.05)$ as compared to high cholesterol diet (positive) control group. The highest decrease level was shown in T3 group (rats fed on hypercholesterolemic diet and received orally $2 \mathrm{ml}$ mallow and hummayd of leaves soup twice daily), followed by $\mathrm{T} 2$ group (rats fed on hypercholesterolemic diet and received orally $1 \mathrm{ml}$ mallow and hummayd of leaves soup twice daily) with mean values of $113.73 \pm 2.19 \mathrm{mg} / \mathrm{dl}$ and $124.26 \pm 3.65 \mathrm{mg} / \mathrm{dl}$, respectively, for total cholesterol and $121.21 \pm 1.99 \mathrm{mg} / \mathrm{dl}$ and $131.40 \pm 3.29 \mathrm{mg} / \mathrm{dl}$, respectively, for triglyceride.

In the same Table, the presented data, also, showed that the positive control group had a significant decrease in serum HDL-c level of $(31.27 \pm 4.89 \mathrm{mg} / \mathrm{dl})$, while the negative group value was $45.32 \pm 3.25 \mathrm{mg} / \mathrm{dl}$. Rats fed on hypercholesterolemic diet with orally mallow and hummayd of leaves soup at 1 and $2 \mathrm{ml}$ daily caused a significant increase in serum HDL-c level at $p<0.05$ and $p<0.01$ (42.77 \pm 4.21 and $46.34 \pm 5.13 \mathrm{mg} / \mathrm{dl}$, respectively) compared with the positive group. The results revealed that T2 and T3 groups had significant decrease in LDL-c and TG serum levels at $p<0.001$ as compared to the positive group. Generally, groups fed on different levels of mallow and hummayd of leaves soup twice daily showed a significantly decrease in serum LDL-c and VLDL-c levels compared to the positive control group. While soup without mallow and hummayd leaves (group T1) caused no significant decrease in serum VLDL-C, 
triglycerides and total cholesterol levels $(35.68 \pm 0.39,178.41 \pm 2.81$ and $153.57 \pm 3.21 \mathrm{mg} / \mathrm{dl}$, respectively) compared to the positive control group.

This results agreed with that reported by several studies (Suido et al., 2002 and Corinna et al., 2005), who reported that daily consumption of green vegetable beverage is useful in lowering serum TC and LDL-c levels in hypercholesterolemic rats. Evidence from prospective cohort studies indicates that a high consumption of plant-based foods such as fruits and green vegetables, nuts, and whole grains is associated with a significantly lower risk of coronary artery disease and stroke. The consumption of leaf vegetable, also, with a hypercholesterolemic diet improved the lipidemic profile and increased excretion of the total cholesterol end-products (Ezz EI-Arab, 2009).

Effect of different dosages of mallow and hummayd leaves soup on risk ratios for rats fed on hypercholestrolemic diet was observed in Table (6). Results showed that the highest risk ratio (I) level for T3 group was 0.40 followed by $\mathrm{T} 2$ group being 0.34 compared to $\mathrm{C}+$ group being 0.19 . While, the risk ratio (II) results of T3 group recorded the lowest value was 0.93 followed by $\mathrm{T} 2$ being 1.29 compared to $\mathrm{C}+$ group being 3.06 .

\section{Conclusion:}

From previous results, it could be concluded that the mallow and hummayd soup improve lipid profiles in experimental model. Therefore, these leafy vegetables are recommended to be mentioned in nutrition education programs. Since it prevent the development of hypercholesterolemia and hyperlipidemia.

Table (2):

Total phenols and flavonoids contents and DPPH scavenging activities of Hummayd and Mallow leaves extracts.

\begin{tabular}{|c|c|c|c|}
\hline & $\begin{array}{c}\text { T.Phenols } \\
(\mathrm{mg} \mathrm{GAE} / \mathrm{g})\end{array}$ & $\begin{array}{c}\text { Flavonoids } \\
(\mathrm{mg} \mathrm{QE} / \mathrm{g})\end{array}$ & $\begin{array}{c}\text { DPPH } \\
(\%)\end{array}$ \\
\hline Mallow & 31.68 & 17.51 & 45.24 \\
\hline Hummayd & 23.4 & 12.30 & 28.13 \\
\hline
\end{tabular}

GAE: Gallic acid equivalent

$\mathrm{QE}:$ quercetin acid equivalent

Table (3):

Sensory evaluation of different rates of mallow and hummayd leaves soup.

\begin{tabular}{|l|l|l|l|l|l|l|}
\hline Mall.:Hum. & \multicolumn{1}{|c|}{$\begin{array}{c}\text { Color } \\
(20)\end{array}$} & $\begin{array}{c}\text { Odor } \\
(20)\end{array}$ & $\begin{array}{c}\text { Taste } \\
(20)\end{array}$ & $\begin{array}{c}\text { viscosity } \\
(20)\end{array}$ & $\begin{array}{c}\text { Appereance } \\
(20)\end{array}$ & \multicolumn{1}{c|}{$\begin{array}{c}\text { Overall } \\
(100)\end{array}$} \\
\hline $1: 1$ & $19.60 \pm 0.10$ & $19.50 \pm 0.10$ & $17.00 \pm 0.20^{\star \star}$ & $19.50 \pm 0.05$ & $18.00 \pm 0.20^{\star}$ & $93.77 \pm 0.14^{\star \star}$ \\
\hline $2: 1$ & $19.65 \pm 0.05$ & $19.50 \pm 0.10$ & $18.50 \pm 0.50^{\star}$ & $19.50 \pm 0.10$ & $19.00 \pm 0.11$ & $96.15 \pm 0.78^{\star}$ \\
\hline $3: 1$ & $19.85 \pm 0.10$ & $19.50 \pm 0.10$ & $19.50 \pm 0.25$ & $19.55 \pm 0.05$ & $19.46 \pm 0.11$ & $97.87 \pm 0.57$ \\
\hline $1: 2$ & $19.50 \pm 0.10$ & $19.05 \pm 0.05$ & $17.35 \pm 0.20^{\star \star}$ & $19.70 \pm 0.10$ & $18.00 \pm 0.10^{\star}$ & $93.60 \pm 0.35^{\star \star}$ \\
\hline $1: 3$ & $19.00 \pm 0.20$ & $19.05 \pm 0.05$ & $16.00 \pm 0.20^{\star \star \star}$ & $19.60 \pm 0.10$ & $19.00 \pm 0.20$ & $92.65 \pm 0.35^{\star \star \star}$ \\
\hline
\end{tabular}

- Differences are significant at $5 \%(P<0.05) .{ }^{\star \star}$ Differences are significant at $1 \%(P<0.01) .{ }^{\star \star \star}$ Differences are significant at $0.1 \% P<0.001$ ) 
Egypt. J. of Nutrition and Health Vol. 10 No. 1 (2015)

Table (4):

Effect of different dosages of mallow and hummayd of leaves soup on body weight gain (BWG), food intake (FI) and food efficiency ratio (FER) for rats fed on hypercholestrolemic diet.

\begin{tabular}{|c|c|c|c|}
\hline Groups & $\begin{array}{c}\text { Body weight gain } \\
\text { (g/28days) }\end{array}$ & $\begin{array}{c}\text { (FI) } \\
(\mathrm{g} / 28 \text { days })\end{array}$ & $\begin{array}{c}\text { FER } \\
(\%)\end{array}$ \\
\hline Negative Control (-) & $28.51 \pm 0.21$ & $350.50 \pm 1.23$ & $8.13 \pm 1.07$ \\
\hline Positive Control (+) & $36.95 \pm 1.31$ & $294.75 \pm 2.70$ & $12.53 \pm 2.05$ \\
\hline T1 & $34.48 \pm 2.05$ & $298.70 \pm 3.10$ & $10.53 \pm 1.54$ \\
\hline T2 & $32.60 \pm 1.26$ & $309.50 \pm 2.35$ & $9.30 \pm 1.43$ \\
\hline T3 & $29.94 \pm 2.15$ & $322.25 \pm 2.98$ & \\
\hline
\end{tabular}

$\mathrm{T} 1: 1 \mathrm{ml}$ of soup without mallow and hummayd leaves twice daily.

$\mathrm{T} 2: 1 \mathrm{ml}$ mallow and hummayd of leaves soup twice daily.

$\mathrm{T} 3: 2 \mathrm{ml}$ mallow and hummayd of leaves soup twice daily.

Table (5):

Effect of different dosages of mallow and hummayd leaves soup on lipid profile for rats fed on hypercholestrolemic diet.

\begin{tabular}{|c|c|c|c|c|c|}
\hline $\begin{array}{l}\text { Experimental } \\
\text { groups }\end{array}$ & $\begin{array}{l}\text { HDL-c } \\
(\mathrm{mg} / \mathrm{dl})\end{array}$ & $\begin{array}{l}\text { LDL-c } \\
(\mathrm{mg} / \mathrm{dl})\end{array}$ & $\begin{array}{l}\text { VLDL-c } \\
(\mathrm{mg} / \mathrm{dl})\end{array}$ & $\begin{array}{l}\text { Triglycerides } \\
\text { )mg/dl( }\end{array}$ & $\begin{array}{l}\text { T.cholesterol } \\
\text { )mg/dl( }\end{array}$ \\
\hline $\begin{array}{c}\text { Normal Control } \\
(-)\end{array}$ & $45.32 \pm 3.25$ & $23.29 \pm 2.47$ & $20.64 \pm 0.12$ & $103.20 \pm 1.35$ & $89.25 \pm 2.15$ \\
\hline $\begin{array}{l}\text { Positive Control } \\
(+)\end{array}$ & $31.27 \pm 4.89$ & $95.71 \pm 2.50$ & $37.10 \pm 0.27$ & $185.51 \pm 3.58$ & $164.08 \pm 2.10$ \\
\hline$T^{1}$ & $30.22 \pm 5.21$ & $87.67 \pm 3.86^{\star}$ & $35.68 \pm 0.39$ & $178.41 \pm 2.81$ & $153.57 \pm 3.21$ \\
\hline$T^{2}$ & $42.77 \pm 4.21^{\star \star}$ & $55.21 \pm 3.14^{\star \star \star}$ & $26.28 \pm 0.25^{\star}$ & $131.40 \pm 3.29^{\star \star \star}$ & $124.26 \pm 3.65^{\star \star}$ \\
\hline$T^{3}$ & $46.34 \pm 5.13^{\star \star \star}$ & $43.15 \pm 2.07^{\star \star \star \star}$ & $24.24 \pm 0.19^{\star \star \star}$ & $121.21 \pm 1.99^{\star \star \star}$ & $113.73 \pm 2.19^{\star \star \star}$ \\
\hline
\end{tabular}
significant at $0.1 \%(P<0.001$

${ }^{\mathrm{T} 1}: 1 \mathrm{ml}$ of soup without mallow and hummayd leaves twice daily.

$\mathrm{T}^{2}: 1 \mathrm{ml}$ mallow and hummayd of leaves soup twice daily.

$\mathrm{T}^{3}: 2 \mathrm{ml}$ mallow and hummayd of leaves soup twice daily 
Table (6):

Effect of different dosages of mallow and hummayd leaves soup on risk ratios for rats feed on hypercholestrolemic diet.

\begin{tabular}{|c|c|c|}
\hline Groups & $\begin{array}{c}\text { Risk ratio (I) } \\
(\mathrm{HDL} / \mathrm{TC})\end{array}$ & $\begin{array}{r}\text { Risk ratio (II) } \\
(\text { LDL/HDL) }\end{array}$ \\
\hline Control (-) & 0.51 & 0.51 \\
\hline Control (+) & 0.19 & 3.06 \\
\hline $\mathrm{T}^{1}$ & 0.20 & 2.90 \\
\hline $\mathrm{T}^{2}$ & 0.34 & 1.29 \\
\hline $\mathrm{T}^{3}$ & 0.40 & 0.93 \\
\hline
\end{tabular}

$T^{1}: 1 \mathrm{ml}$ of soup without mallow and hummayd leaves twice daily.

$\mathrm{T}^{2}: 1 \mathrm{ml}$ mallow and hummayd of leaves soup twice daily.

$\mathrm{T}^{3}: 2 \mathrm{ml}$ mallow and hummayd of leaves soup twice daily 


\section{References}

Abdel-Raheim, E; El-Sadany and Wasif, M. (1995):

Chemical dynamic of hypocholesterolemic action of Balanittis Egyption fruits. J. of Food Chem., 20: 69-78.

Allain, C., Poon, L. and Chan, C. (1974).

Enzymatic determination of total serum cholesterol. Clin. Chem., 20:470-475.

Ames, B. N.; Shigenaga, M. K. and Hagen, T. M. (1993):

Oxidants, antioxidants, and the degenerative diseases of aging. Proc Natl Acad Sci., 90:7915

Arnous, A.; Makris, D. P. and Kefalas, P. (2001):

Effect of principal polyphenol components in relation to antioxidant characteristics of aged red wines. J. Agric. Food Chem., 49: 5736.

Brand-Williams, W., Cuvelier, M. E. and Berset, C. (1995):

Use of a free radical method to evaluate antioxidant activity. LWT- Food Sci. and Technol., 28: 25.

Buyukokuroglu, M. E.; Gulcin I.; Oktay M. and Kufrevioglu O. I. (2001):

In vitro antioxidant properties of dantrolene sodium. Pharm Res., 44:491-495.

Chapman D. G.; Castilla, R. and Champell, J. A. (1959):

Evaluation of protein efficiency ratio-can. J. Biochem. Physiol., 37:679-686.

Corinna, K. K.; Adel, L.; Garcia, P. C.; Dagnelie, C. S.; Norbert, J. L. and Ingrid, H. (2005):

Long-term consumption of a raw food diet is associated with favorable serum LDL-cholesterol and triglycerides but also with elevated plasma homocysteine and low serum HDL-cholesterol in humans. J. Nutr., 135: 23722378.

El-Bakry, A. A., Mostafa, H. A. M. and Alam, E. A. (2011):

Evaluation of some growth parameters and chemical composition of invitro grown seedlings of Rumex vesicarius L. (Polygonaceae). J. Am. Sci., 7:170-179.

El-Hawary, S. A.; Sokkar, N. M.; Ali, Z. Y. and Yehia, M. M. (2011):

A profile of bioactive compounds of Rumex vesicarius L. J. Food Sci., 76(8): 1195-1202.

Ezz El-Arab A. M. (2009):

A diet rich in leafy vegetable fiber improves cholesterol metabolism in high-cholesterol fed rats. Pakistan Journal of Biological Sciences, 12: 1299-1306.

Fossati, T. and Principe, L. (1982):

Serum triglycerides determined colorimetrically with an enzyme that produces hydrogen peroxide. Clin.chem., 28: $2077-80$.

Friedwald, W.T.; Leve, R. I. and Fredrichson, D. S. (1972):

Estimation of concentration of low-density lipoprotein separated by three different methods. Clin. Chem., 18: 499-502. 
Gautam, R.; Saklani, A. and Jachak, M. (2010):

Indian medicinal plants as a source of antimycobacterial agents. J. of Ethnopharmacology, 110: 200-234.

Gil, M. I.; Tomas-Barberan, F. A.; Hess Pierce, B.; Holcroft, D. M., and Kader, A. A. (2000): Antioxidant activity of pomegranate juice and its relationship with phenolic composition and processing. Journal of Agricultural and Food Chemistry, 48, 4581-4589.

Jan, G.; Khan, M. A. and Gul, F. (2009):

Ethnomedicinal plants used against jaundice in Dir Kohistan Valleys (NWFP), Pakistan. Ethno Leaflets, 13: 1029-1041.

Jelili, A. B.; Temitope, O. A.; John, O. F.; Victor A. A.; Luwatosin, A. A. and Oyeronke, A. O. (2011):

Lipid peroxidation inhibition and antiradical activities of some leaf fractions of Mangifera indica. J. Acta Poloniae Pharmaceutica-Drug Research, 68 (1): 23-29.

Joyeux, M.; Lobstein, A.; Anton, R. and Mortier, F. (1995):

Comparative anti-lipoperoxidant, anti-necrotic and scavenging potencies of terpenes and biflavones from Ginko and some flavonoids. Planta Med., 61: 126-129.

Kathi, J. and Kemper, M. D. (1999):

Sorrel (Rumex acetosa L.). The Longwood Herbal Task Force (http://www.mcp.edu/herbal/default.htm) and The Center for Holistic Pediatric Education and Research.

Kojuri, J.;Vosoughi, A. R. and Akrami, M. (2007):

Effects of Anethum graveolens and garlic on lipid profile in hyperlipidemic patients. Lipids Health Dis. (1): 5:6.

Lane-Peter, W. A. and Pearson, A. E. (1971).

Dietary Requirements. In: The Laboratory Animal Principles and Practice, Lane-Peter, W.A. and A.E. Pearson (Eds.). Academic Press, London, New York, pp: 142.

Larmond, E. (1970):

Methods for sensory evaluation of food. Canada Dept. Agric. Publication 1284.

Londonkar, R. L. and Tukappa, A. K. (2013):

Pharmacognostical Evaluation and Comparative Phytochemical Screening of Rumex vesicarius L.Intern. J. of Phytomed., 5:146-153.

Lopes-Virella, M. F.; Stone, S.; Ellis, S. and Collwellm, J. A. (1977):

Cholesterol determination in high density lipoproteins separated by three different methods. Clin. Chem., 23 (5):882-893.

Mandaville j. P. (1990):

Flora of eastern Saudi Arabia. Kegan Paul International, London and New York.

Marja, P. K.; Anu, I. H., Heikki, J. V.; Jussi-Pekka, R.; Kalevi, P.; Tytti, S. K. and Marina, H. (1999):

Antioxidant activity of plant extracts containing phenolic compounds. Journal of Agricultural and Food Chemistry, 47, 3954-3962. 


\section{Egypt. J. of Nutrition and Health Vol. 10 No. 1 (2015)}

Marouane, W.; Soussi, A.; Murat, J.; Bezzine, S. and Feki, A. E. (2011):

The protective effect of Malva sylvestris on rat kidney damaged by vanadium. Lipids Health Dis. 10: 65-72.

Matos, S. L.; Paula, H.; Pedrosa, M. L.; Santos, R. C.; Oliveira, E. L.; Chianca, J. R. and Silva, M. E. (2005): Dietary models for inducing hypercholesterolemia in rats. Brazilian Archives Biol. Technol., 48(2):203-209.

Mustafa, A. and Ali, M. (2011):

New steroidal lactones and homomonoterpenic glucoside from fruits of Malva sylvestris L. Acta Pol Pharm 68: $393-401$.

Pirbalouti, A. G.; Yousefi, M.; Nazari, H.; Karimi, I. and Koohpayeh A. (2009):

Evaluation of burn healing properties of Arnebia euchroma and Malva sylvestris. Electr. J. Biol. 5: 62-66.

Rao, K. V.; Sunitha, C. H.; David Banji, S. S. and Saikumar, P. (2011):

Pharmacognostic studies on Rumexvesicarius. Asian J Plant Sci . 1(1): 102-115.

Razavi, S. M.; Zarrini, G.; Molavi, G.and Ghasemi, G. (2011):

Bioactivity of Malva sylvestris L., a medicinal plant from Iran. Iranian J. Basic. Med. Sci. 14: 574-579.

Schuler, P. (1990):

. Natural Antioxidants Exploited Commercially, in Food antioxidants. In: Hudson BJF, ed. London: Elsevier. 99140.

SPSS (1998):

Statistical Package for Social Science, Computer Software, Ver. 11.0 SPSS Company. London, UK.

Suido, H.; Tanaka, T.; Tabei, T.; Takeuchi, A.; Kishimoto, T. and Higashino, K. (2002):

A mixed green vegetable and fruit beverage decreased the serum level of low-density lipoprotein cholesterol in hypercholesterolemic patients. J. Agric. Food Chem., 50 (11): 3346-3350.

Tabaraki, R.; Yosefi, Z. and Gharneh H. A. (2012):

Chemical composition and antioxidant properties of Malva sylvestris L. J. Res. Agri. Sci., 8: 59-68.

Tavares, L.; Carrilho, D.; Tyagi, M.; Barata, D.; Serra, T.A.; Duarte, M.; Duarte, M.R.; Feliciano, R. P.; Chicau, M. P.; Espírito-Santo, M. D.; Ferreira, R. B.; Boavida, R. and Santos, C. N. (2010):

Antioxidant capacity of macaronesian traditional medicinal plants. Molecules; 15: 2576-2592.

Tukan, S. K.; Takruri, H. R. and Al-Eisawi, D. M. (1998):

The use of wild edible plants in the Jordanian diet. Int. J. Food Sci. Nutr., 49: 225-235.

Velavan, S.; Nagulendran, K.; Mahesh, R. and Hazeena, B. (2007):

In vitro antioxidant activity of Asparagus racemosa root. Pharmoco Mag Res Art.; 3:26-33. 
امكانية الاستفادة من أوراق الخبيزة والحميض فى تحسين صورة دهون الدم بفئران التجارب المصابة بارتفاع الكوليستيرول في تحسن صول

\author{
عبد المنعم سامى عبل المنعم حشيش

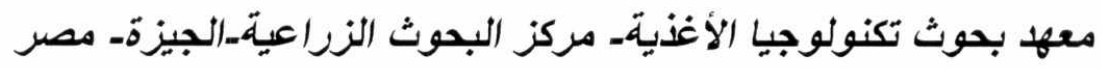 \\ الملخص العربي
}

تعتبر أوراق الخبيزة والحميض من أثهر الخضروات الورقية الثنانعة بالريف المصرى. تم الحصول على المستخلص المانى لتلكا

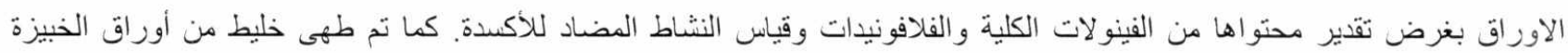

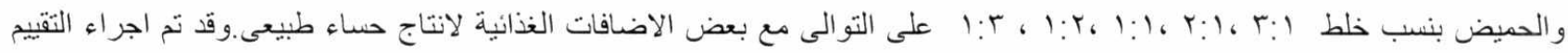

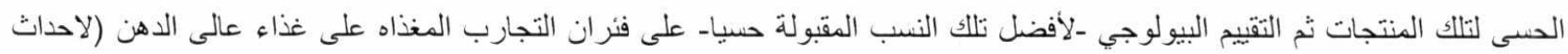

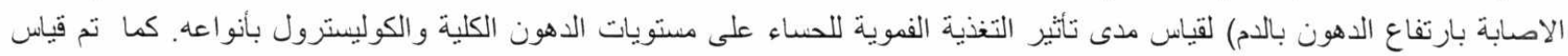

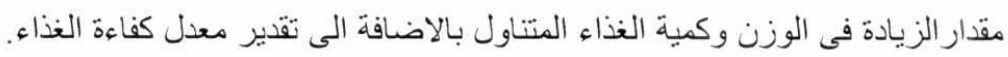

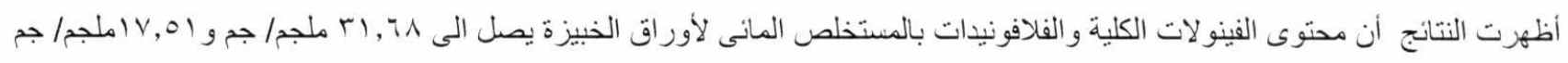

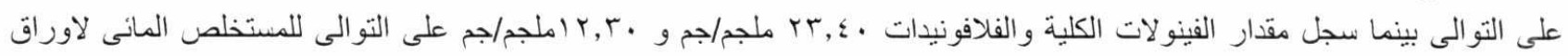

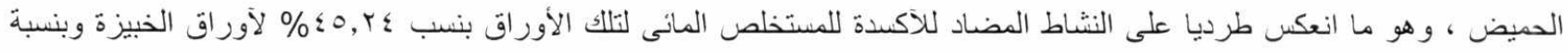

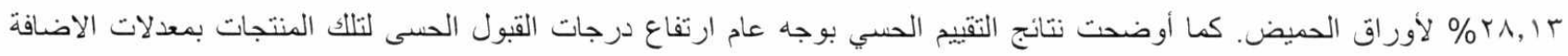

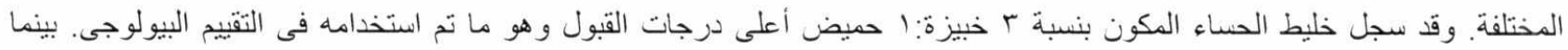

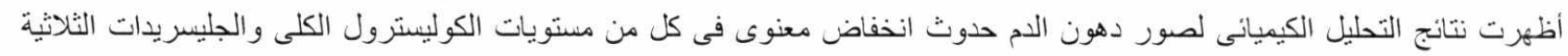

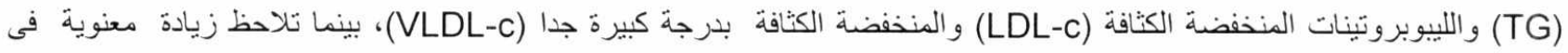

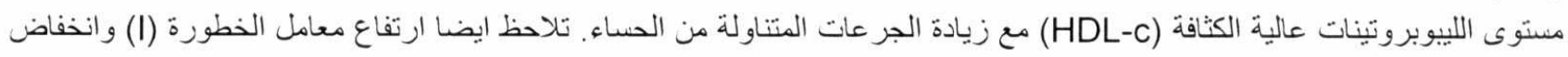

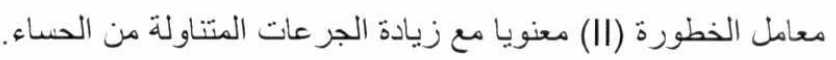

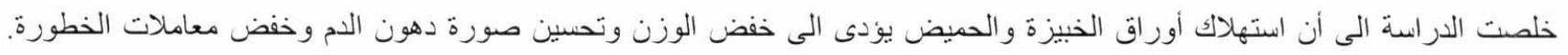

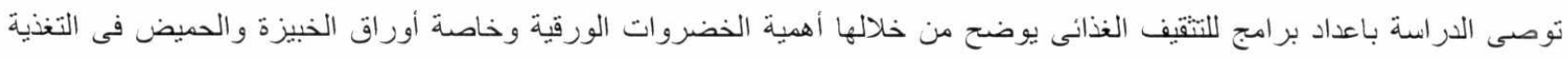

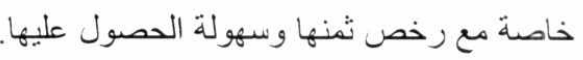

